\title{
Flood Risk Code Mapping Using Multi Criteria Assessment
}

\author{
Ragab Khalil1,2 \\ ${ }^{1}$ Civil Engineering Department, Faculty of Engineering, Assiut University, Assiut, Egypt \\ ${ }^{2}$ Landscape Architecture Department, Faculty of Environmental Design, KAU, Jeddah, Saudi Arabia \\ Email: khalilragab@yahoo.com
}

How to cite this paper: Khalil, R. (2018) Flood Risk Code Mapping Using Multi Criteria Assessment. Journal of Geographic Information System, 10, 686-698. https://doi.org/10.4236/jgis.2018.106035

Received: November 13, 2018 Accepted: December 3, 2018 Published: December 6, 2018

Copyright $\odot 2018$ by author and Scientific Research Publishing Inc. This work is licensed under the Creative Commons Attribution International License (CC BY 4.0).

http://creativecommons.org/licenses/by/4.0/

\begin{abstract}
Flash flood is a dangers natural disaster causes lots of structure damage, traffic collapse, economic defects and human life loss. An efficient way to reduce its effects is preparing flash flood mapping to identify zones at risk due to flood. Flash flood mapping is a powerful tool for urban planners, traffic and infrastructure engineers, emergency and rescue services. This article proposes an approach utilizes remote sensing (RS) and geographic information system (GIS) to prepare flood risk code (FRC) map for Jeddah city, Saudi Arabia. The proposed approach applied the Curve Number (CN) method of flood modelling and uses runoff depth, land use, soil hydrological parameters, surface slope, and longest flow path to generate FRC. SPOT satellite image of the study area was classified to generate land use map, Digital Elevation Model (DEM) was used for generating slope map and for hydrology analysis using HEC-GeoHMS tool, and soil properties were generated from scanned soil maps. All data were integrated in ArcGIS 10.4.1 to prepare the final flood risk map. The results show that a precipitation of $106.3 \mathrm{~mm}$ will generate 136.5 million $\mathrm{m}^{3}$ of flood water. The results according to the developed flood risk code show that due to this amount of precipitation, about 1 million people live in Jeddah are prone to extreme flood risk and about 2 million of population are at major risk, the rest of population (about 0.5 million) are vulnerable to moderate to minor fold risk. The approach was verified using ground truth data and proofed precision.
\end{abstract}

\section{Keywords}

Remote Sensing, GIS, Multi Criteria, Flood Risk Code, Runoff, Time of Concentration

\section{Introduction}

The destructive effect of flash flood on properties and road networks make it one 
of the most dangerous natural hazards. Adopting an appropriate approach beside acquiring land cover data and related hydrological parameters is the way to predict sites sensitive to flooding [1]. The calculation of runoff coefficient which is the part of rainfall that turns to runoff as defined by [2] is the corner stone for flood estimation which affects many related activities such as flood damage determination, flood control plans and structures, water resources management and flood risk assessment [3] and [4]. There are several methods to estimate the flood parameters based on the morphometric characteristics of flood basins. Reference [3] categorized these methods according to their complicity into three groups simple, moderate and complex. Reference [5] summarized five methods for quantitative analysis of drainage basin morphometry. These methods are El-Shamy's approach, the morphometric ranking method, Wahid's flash flood rating method, Morphometric hazard degree assessment method and the curve number $(\mathrm{CN})$ method. The curve number $(\mathrm{CN})$ method was applied in this research as it requires few data, its complicity is moderate, and it is widely used for flood estimation [6]. CN method uses storm rainfall depth, land use and soil infiltration properties of a catchment for predicting of direct runoff depth. Remote sensing imageries are main spatial data source to produce land use and soil maps needed for flood properties estimation. Delineation of hydrological catchments, map overlay, and data analysis make GIS a powerful tool in hydrological modelling. For these reasons many studies applied GIS and remote sensing in flood calculations e.g. [7]-[17]. The use of Digital Elevation Model (DEM) facilitated the procedure of watershed delineation. The DEM provides the basic input for the delineation of the catchment area and generation of drainage networks in GIS environment. Many researches attempted to configure a relationship between basin morphometric parameters and flood to produce a flood hazard risk map. References [5], [18] [19] and [20] ranked subbasins within a basin according to a series (more than 20 in some researches) of calculated morphometric parameters in order to produce a flood hazard risk map. The raw value for each parameter was normalized to ranged from ( 0 to 1$)$ to minimize the value of total flood risk after summation of all the parameters. Reference [21] used only 5 morphometric parameters to produce the flood risk map. Other researchers used only one morphometric parameter to produce the flood risk map e.g. [3] used the runoff volume, [22] used flow velocity, [23] suggested using travel time, [24] acknowledged peak flow magnitude as a primary flood hazard indicator, and [25] used the peak flow rate as a flood hazard indicator. In this study a Flood Risk Code (FRC) was proposed to map the flood hazard zones in Jeddah. Two effective parameters were used to generate the FRC. These parameters are time of concentration (Tc) and runoff depth $(\mathrm{Q})$. The Tc has functions of flow length, slope and curve number which has functions of land use and soil properties. The $\mathrm{Q}$ has functions of rainfall, slope and curve number. Using these two factors (Tc and Q) is exactly as using rainfall, land use, soil, slope and flow length for computing FRC. Each parameter was ranked by how risky it is on a scale of 1 to 4 , with 4 being the extreme risk. The overlay analysis technique was used to generate the flood risk code map. 


\section{Study Area}

The proposed approach was applied on Jeddah city, Saudi Arabia. Jeddah lies at the middle of west region of Saudi Arabia and represents the important commercial port. It's surrounded by a chain of mountains at the east side from which the flood begins and flow through the city to the sea. Its population exceeds 3.4 million people live in an area of about $5460 \mathrm{~km}^{2}$. Although its weather condition is hot, it receives a rain storm from time to time. In November 2009 and January 2011, Jeddah was hit by a rainfall storm of 80 and $124 \mathrm{~mm} /$ day respectively as mentioned by [26]. These were examples of flash flood which strike occasionally and characterized by short durations and harmful results as mentioned by [27]. The watershed area that affected the city is located between $\left(21^{\circ} 15^{\prime} \mathrm{N}, 21^{\circ} 50^{\prime} \mathrm{N}\right)$ and $\left(39^{\circ} 0^{\prime} \mathrm{E}, 39^{\circ} 35^{\prime} \mathrm{E}\right)$ as shown in Figure 1.

\section{Data}

The data set used in this study contain a SPOT satellite multispectral image of $2.5 \mathrm{~m}$ resolution used to generate the land use map as shown in Figure 2, ASTER DEM $30 \mathrm{~m}$ spatial resolution is provided on line cost free to extract slope data and stream network, soil maps used to generate the soil data as shown in Figure 3 and the rainfall data for a period of 42 years extending from January 1971 to December 2012 for Jeddah from two rain gauge stations, J134 and JMPE (airport station). The maximum annual daily rainfall for the two stations is shown in Figure 4.

\section{Methodology}

The proposed GIS and RS based approach for flood hazard mapping consists of several steps. These steps are performed in ArcGIS environment using the proper tools for each. The sequences of these steps are schematically shown in Figure 5 and can be summarized as following:

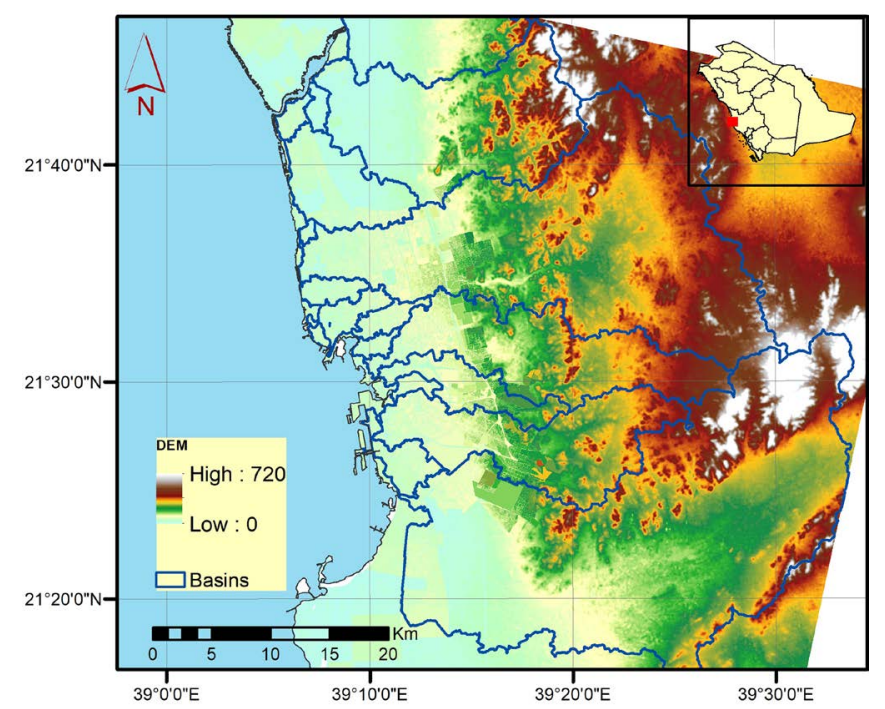

Figure 1. The study site and its catchment area. 


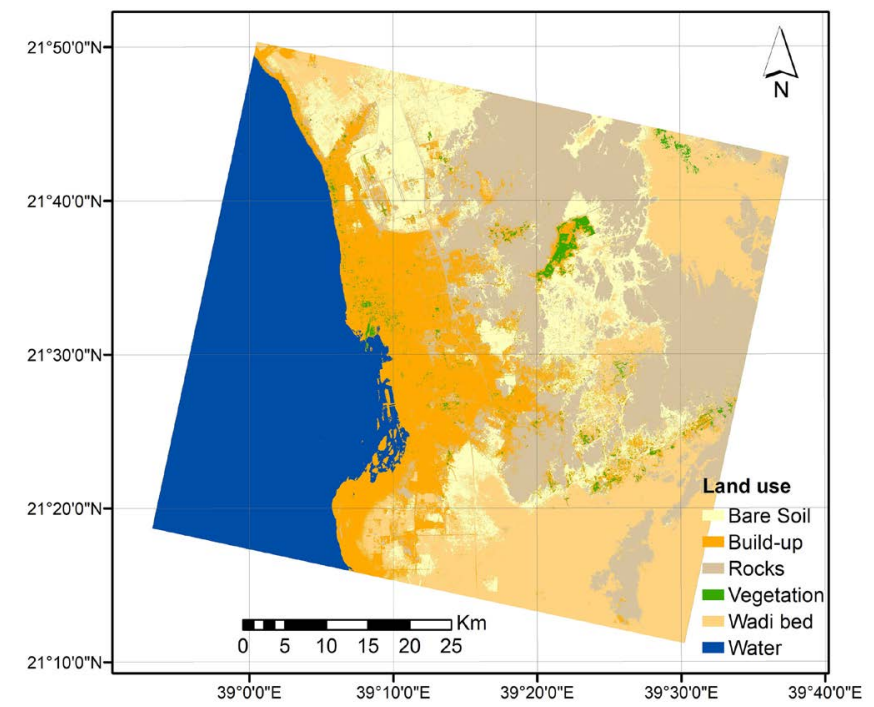

Figure 2. Land use map for the study area generated from classification of SPOT image.

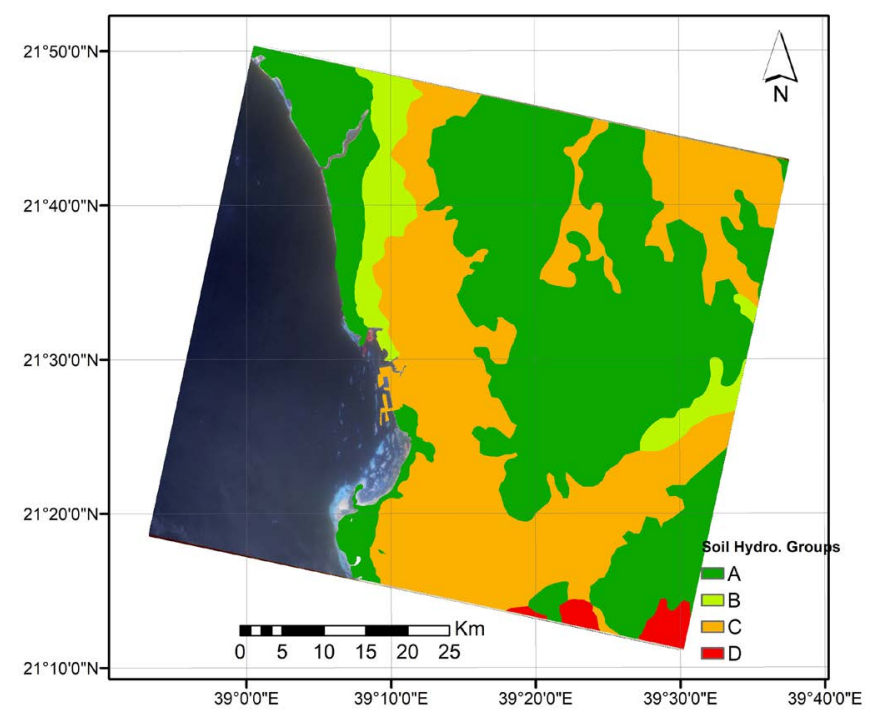

Figure 3. Soil hydrological group map for the study area.

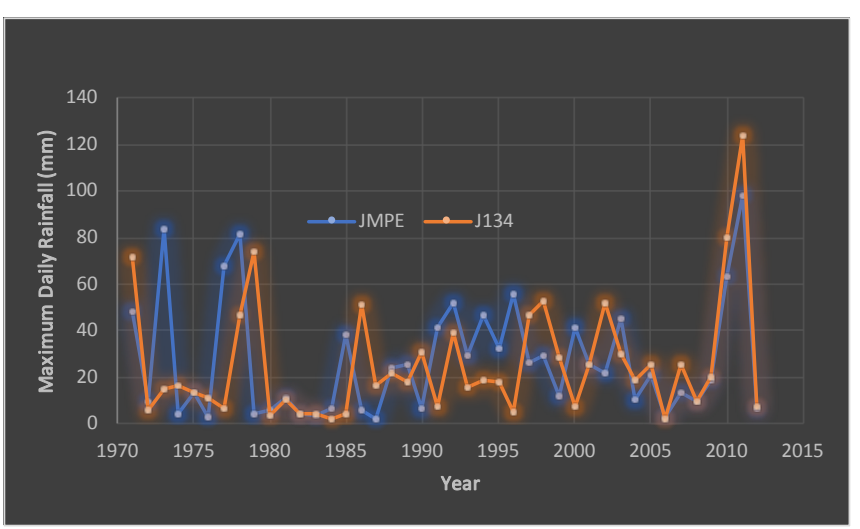

Figure 4. The maximum annual daily rainfall $(\mathrm{mm})$ recorded at JMPE and J134 stations from 1971 to 2012. 


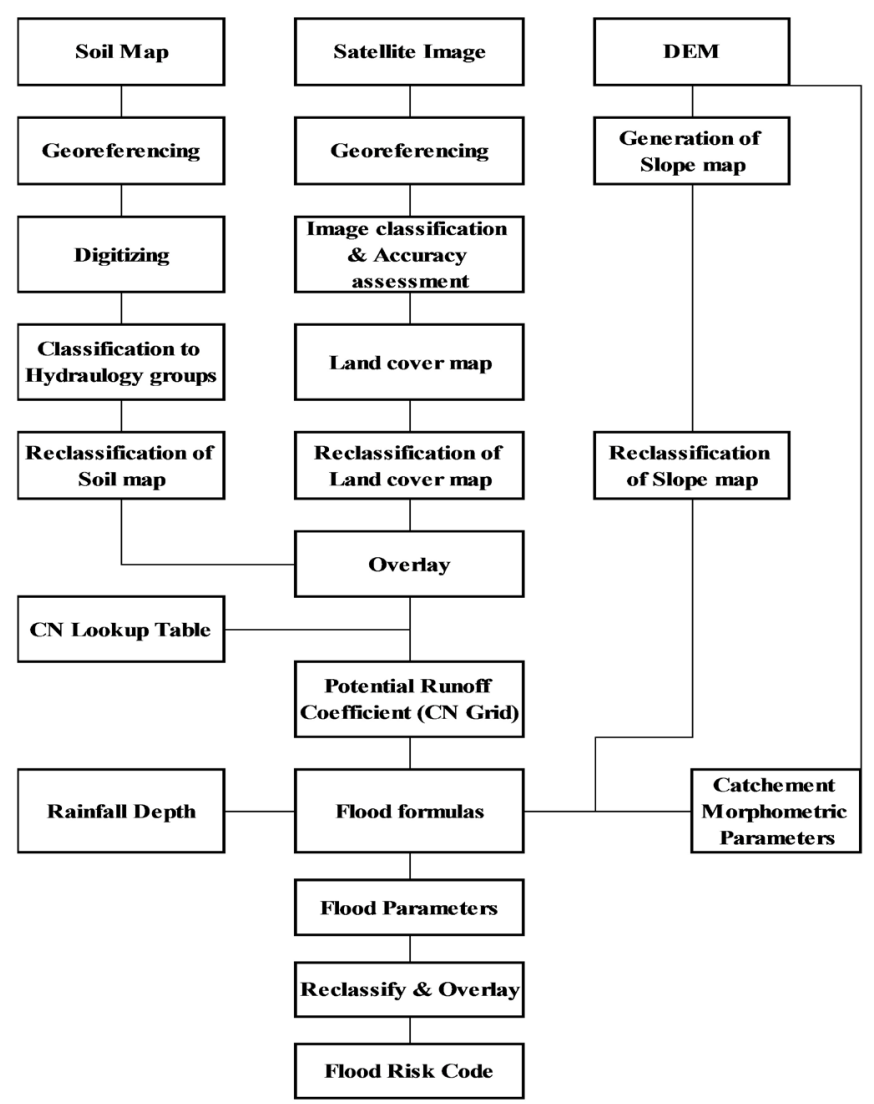

Figure 5. Methodology for Flood hazard mapping based on GIS and RS.

- Scanning and Georeferencing the soil maps. The soil polygons were digitized, and the soil types were extracted from the maps. Soil types was categorized to Hydrological Soil Groups (HSG) according to [28].

- Georeferencing, segmentation of SPOT image then the supervised classification technique was applied to convert the image to land use thematic map. The thematic map then converted to polygons.

- Generate slope map using DEM data

- Build the runoff curve number lookup table according to the land use map and reference [28].

- Generating curve number grid (CN Grid) using the former generated layers using HEC-GeoHMS tool.

- Generating the geomorphological and hydrological parameters such as the drainage network, the main basins and the subbasins of each main catchment, and the longest flow path in each catchment using HEC-GeoHMS tool.

- The rainfall intensity for a 100 -years return period has been estimated as $106.3 \mathrm{~mm}$ and is used in the current research study. This estimation was based on the rainfall data of two rainfall gauges in Jeddah as shown in 5.1.

- Apply flood formulas to calculate runoff depth, time of concentration and runoff volume for subbasins. 
- Reclassify the runoff depth and time of concentration values and rank them on scale of 1 to 4 .

- Integrating all data in a GIS environment to generate flood risk code and flood maps.

- Evaluate the proposed approach using ground truth data.

\section{Data Processing}

\subsection{Rainfall-Runoff Analysis}

Among many of the probability density functions that used to estimate the rainfall depth at a specific return period, the Gumbel or Extreme Value Type I (EV1) function was recommended as it provided the best prediction [29]. In this function the magnitude $\mathrm{X}_{\mathrm{T}}$ of a hydrologic event may be calculated using Chow Equation (1) [30]

$$
X_{T}=\mu+K_{T} \cdot \sigma
$$

where

$\mu$ : the mean value of the data

$\sigma$. the standard deviation

$K_{T}$ : the frequency factor

$T$ : the return period

The frequency factor can be calculated using Equation (2) [30]

$$
K_{T}=-\frac{\sqrt{6}}{\pi}\left\{0.5722+\ln \left[\ln \left(\frac{T}{T-1}\right)\right]\right\}
$$

The estimated rainfall depth for different return periods for the two rain gauge stations are shown in Table 1.

\subsection{Catchment Morphometric Parameters}

The curve number $(\mathrm{CN})$ method was used to estimate the run off over the study area. The $\mathrm{CN}$ is an indicator of infiltration capacity for each soil type and is based on land use, hydrologic soil group and surface slope. The details of generating land use map through classification of SPOT image, generating the hydrologic soil group map and slope map for the study area can be found in [31]. The morphometric parameters are calculated at the sub-basin level. These parameters include the main basins, sub-basins, sub-basin- $\mathrm{CN}$, time of concentration and the longest flow path for each sub-basin were generated in ArcGIS using HEC-GeoHMS tool.

Table 1. Estimated daily rainfall ( $\mathrm{mm}$ ) for different return periods.

\begin{tabular}{ccccccc}
\hline Return period (years) & 5 & 10 & 20 & 25 & 50 & 100 \\
\hline 41024 station & 45.5 & 60.0 & 74.0 & 78.4 & 92.0 & 105.5 \\
J134 station & 44.5 & 59.5 & 73.8 & 78.4 & 92.4 & 106.3 \\
\hline
\end{tabular}




\subsection{Flood Hazard Parameters}

The flood hazard parameters such as watershed storage, runoff depth, and volume of runoff were calculated using ArcGIS field calculation capability. The flood hazard parameters were calculated according to the $\mathrm{CN}$ method equations published in Technical Report 55 [28]. Equation (3) used to calculate watershed storage, Equation (4) to calculate the runoff depth while Equation (5) used to calculate runoff volume for subbasins to demonstrate the local effect of runoff.

$$
\begin{gathered}
S=(25400 / C N)-254 \\
Q=(P-0.2 S)^{2} /(P+0.8 S) \\
V_{Q}=(Q \cdot A / 1000)
\end{gathered}
$$

where

$S$ : the watershed storage $(\mathrm{mm})$,

$Q$ : the direct runoff depth (mm),

$P$ : rainfall depth for a specific return period $(\mathrm{mm})$,

$C N$ : the curve number,

$V_{Q}$ : Volume of runoff $\left(\mathrm{m}^{3}\right)$,

$A$ : Basin area $\left(\mathrm{m}^{2}\right)$.

The time of concentration is the time required for a water drop to travel from the watershed divide (the most distant point of the watershed) to the watershed outlet. There are several methods to calculate the concentration time. The $\mathrm{CN}$ method was used to estimate the time concentration. Equation (6) [32] used to estimate the time of concentration as follows:

$$
T_{C}=\frac{L^{0.8}\left(\frac{1000}{C N}-9\right)^{0.7}}{441 Y^{0.5}}
$$

where

$$
\begin{aligned}
& \mathrm{Tc}=\text { time of concentration, hours } \\
& \mathrm{L}=\text { longest flow path, } \mathrm{m} \\
& \mathrm{Y}=\text { average watershed slope (percent) } \\
& \mathrm{CN} \text { = Curve number }
\end{aligned}
$$

\section{Results \& Discussion}

The proposed approach of using RS and GIS for estimating flood hazard parameters was applied on Jeddah watershed affected area. The results show that there are 12 basins in Jeddah 7 of them are major and 5 are minor as shown in Figure 6. The minimum area of the major basins was $59.04 \mathrm{~km}^{2}$ with a flow path of $12.7 \mathrm{~km}$ while the maximum area was $555.5 \mathrm{~km}^{2}$ with a flow path of $77.4 \mathrm{~km}$. Their time of concentration ranges from 5.87 to 13.80 hours. The areas of the minor basins range from 6.9 to 15.5 square kilometers, their longest flow paths range from 7.48 to 10.23 kilometers, and their time of concentration of the major basins ranges from 2.81 to 4.14 hours. Table 2 presents some geometrical 
and flood parameters including the runoff volume and the time of concentration of the 12 basins. A rainfall depth (P) equals $106.3 \mathrm{~mm}$ for a return period of 100 years as shown in Table 1 was used to calculate the flood characteristics.

The results presented in Table 2 show that the time of concentration (Tc) increased with increasing the flow length and decreasing the surface slope. The curve number and the surface slope have the great effect on time of concentration (Tc). The runoff depth $(\mathrm{Q})$ is directly proportional to the curve number and inversely proportional to slope. It is affected greatly by the curve number value.

In this study a Flood Risk Code (FRC) was proposed to map the flood hazard zones in Jeddah. The two effective parameters Tc and Q were used to generate the FRC. The Tc has functions of flow length, slope and curve number which has functions to land use and soil properties. The $\mathrm{Q}$ has functions of rainfall, slope and curve number. Using these two factors (Tc and Q) is exactly as using rainfall, land use, soil, slope and flow length for computing FRC.

The Tc and Q were computed for all subbasins in the study area. The Tc values range from 0.26 to 5.80 hours and the Q values range from 43.7 to $94.5 \mathrm{~mm}$. The Tc and Q were ranked by how risky they are on a scale of 1 to 4 , with 4 being the extreme risk. The rank value increases with increasing the $\mathrm{Q}$ and decreasing the Tc according to the limits shown in Table 3.

The FRC is generated using overlay analysis in ArcMap 10.4.1 software. The values of FRC were classified into Minor, moderate, Major and Extreme risk and used for mapping the Flash Flood Hazard zones as shown in Figure 7.

Table 2. Geometrical and flood parameters of basins.

\begin{tabular}{|c|c|c|c|c|c|c|c|}
\hline Basin & $\begin{array}{l}\text { Area } \\
\left(\mathrm{km}^{2}\right)\end{array}$ & $\begin{array}{c}\text { Longest flow } \\
\text { path }(\mathrm{m})\end{array}$ & $\mathrm{CN}$ & Slope \% & $\begin{array}{c}\text { Runoff } \\
\text { depth }(\mathrm{mm})\end{array}$ & $\begin{array}{c}\text { Runoff } \\
\text { volume } \\
\text { (million } \mathrm{m}^{3} \text { ) }\end{array}$ & $\begin{array}{c}\text { Time of } \\
\text { concentration } \\
\text { Tc }(h)\end{array}$ \\
\hline B1 & 555.47 & $77,410.48$ & 88.8 & 5.63 & 75.8 & 42.553 & 13.80 \\
\hline B2 & 143.28 & $32,825.69$ & 91.4 & 5.25 & 82.5 & 11.452 & 6.46 \\
\hline B3 & 192.27 & $42,556.96$ & 90.3 & 4.60 & 80.3 & 14.382 & 8.91 \\
\hline B4 & 448.60 & $62,297.97$ & 90.7 & 5.83 & 80.8 & 36.001 & 10.54 \\
\hline B5 & 59.04 & $12,715.07$ & 88.7 & 1.37 & 75.5 & 4.501 & 6.60 \\
\hline B6 & 201.10 & $35,140.56$ & 90.5 & 7.62 & 80.4 & 16.458 & 5.87 \\
\hline B7 & 84.79 & $19,882.92$ & 87.5 & 3.22 & 72.7 & 6.224 & 6.46 \\
\hline B8 & 14.61 & $10,231.69$ & 93.6 & 2.11 & 88.1 & 1.287 & 3.62 \\
\hline B9 & 9.40 & 7486.95 & 93.6 & 2.14 & 88.0 & 0.827 & 2.81 \\
\hline B10 & 6.98 & 9332.22 & 93.5 & 2.12 & 87.8 & 0.613 & 3.38 \\
\hline B11 & 15.47 & 9040.97 & 91.2 & 1.64 & 81.8 & 1.265 & 4.14 \\
\hline \multirow[t]{2}{*}{ B12 } & 11.21 & 8113.69 & 91.5 & 1.43 & 82.3 & 0.923 & 4.04 \\
\hline & & & & $\begin{array}{c}\text { Total } \\
\text { volume }\end{array}$ & 136.486 & & \\
\hline
\end{tabular}


Table 3. Limit values of ranks.

\begin{tabular}{ccc}
\hline Rank & Runoff depth Q $(\mathrm{mm})$ & Time of concentration Tc (h) \\
\hline 1 & $<55 \mathrm{~mm}$ & $>4 \mathrm{~h}$ \\
2 & $55.01-65 \mathrm{~mm}$ & $3.01-4 \mathrm{~h}$ \\
3 & $65.01-75 \mathrm{~mm}$ & $2.01-3 \mathrm{~h}$ \\
4 & $>75 \mathrm{~mm}$ & $<2 \mathrm{~h}$ \\
\hline
\end{tabular}

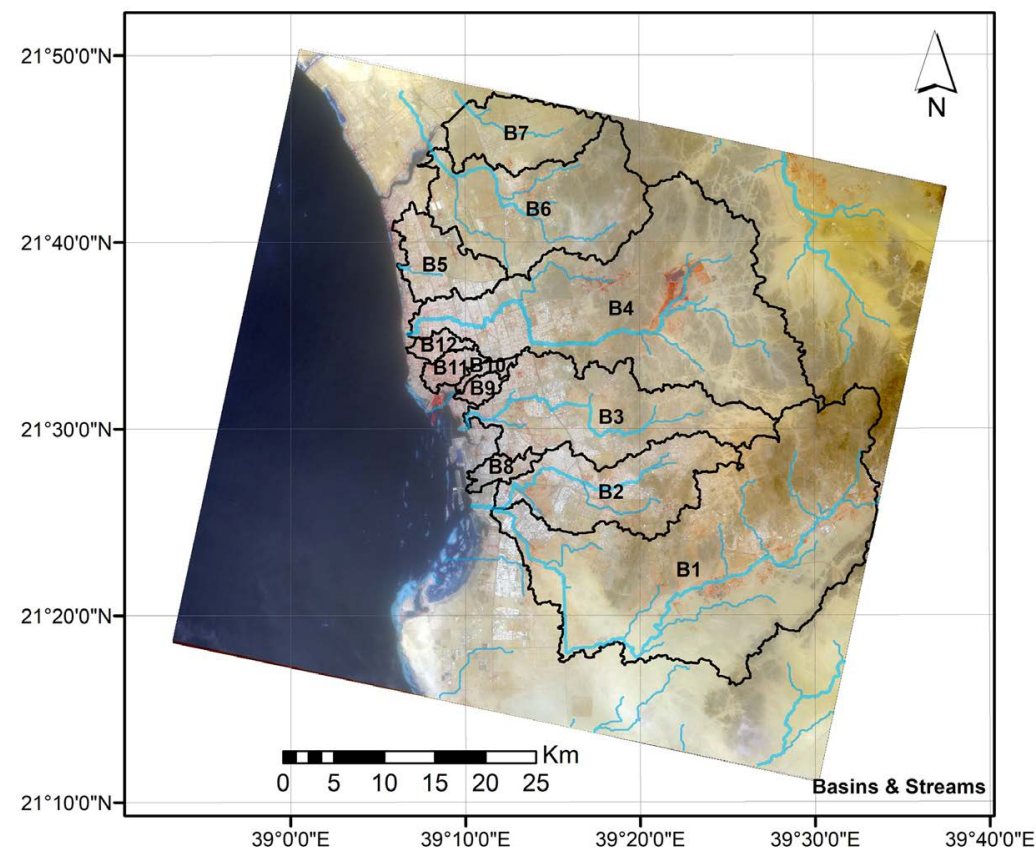

Figure 6. Basins and main streams.

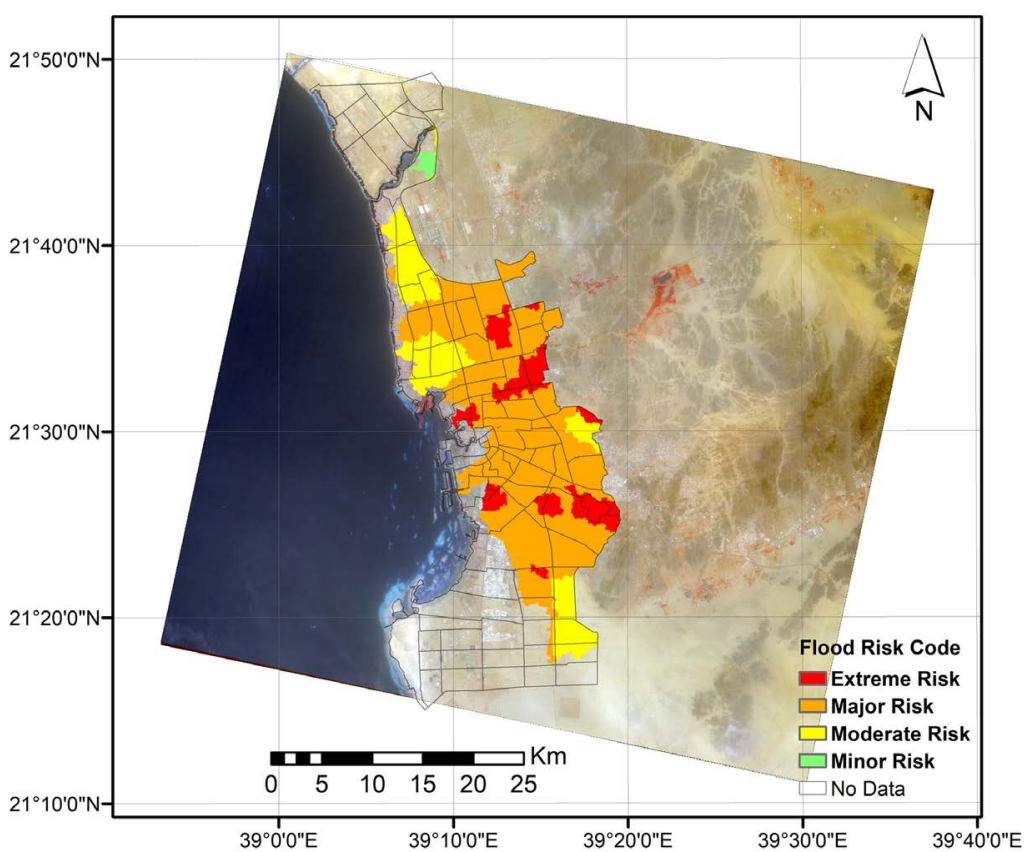

Figure 7. Flood Risk Code. 
The areas at risk were obtained by overlaying the flood risk code map with the districts layer. The area and population affected by flood were summarized in Table 4 and may be used for and floodplain development control. More than 850,000 capita in 24 districts are vulnerable to extreme flood risk. About 2,320,000 in 63 districts are vulnerable to major risk. More than 560,000 in 18 districts are vulnerable to moderate flood risk. The rest of districts are vulnerable to minor flood risk or no data available about them. Jeddah area has received a rainstorm of $68 \mathrm{~mm}$ /day (max. value) in 21 November 2017 and the municipality of Jeddah published a map showing the road opening status. This map was used to verify the proposed approach by overlying it with the generated flood risk code map as shown in Figure 8. The figure proof the validity of the proposed approach as the closed roads due to flood (red lines) are coincide with major and extreme risk code, roads vulnerable to be closed (orange lines) are coincide with major risk code, the save roads (green lines) are coincide with moderate and minor risk codes.

Table 4. Area and population at flash flood risk.

\begin{tabular}{cccc}
\hline FRC & No. of Districts & Area $\left(\mathrm{m}^{2}\right)$ & Population \\
$\begin{array}{c}\text { Minor } \\
\text { Risk } \\
\text { Moderate } \\
\text { Risk }\end{array}$ & 1 & $15,268,292$ & 15,962 \\
Major & 18 & $167,460,834$ & 568,264 \\
Risk & 63 & & \\
Extreme & & $484,813,152$ & $2,319,862$ \\
Risk & 24 & $208,481,125$ & 857,182 \\
\hline
\end{tabular}

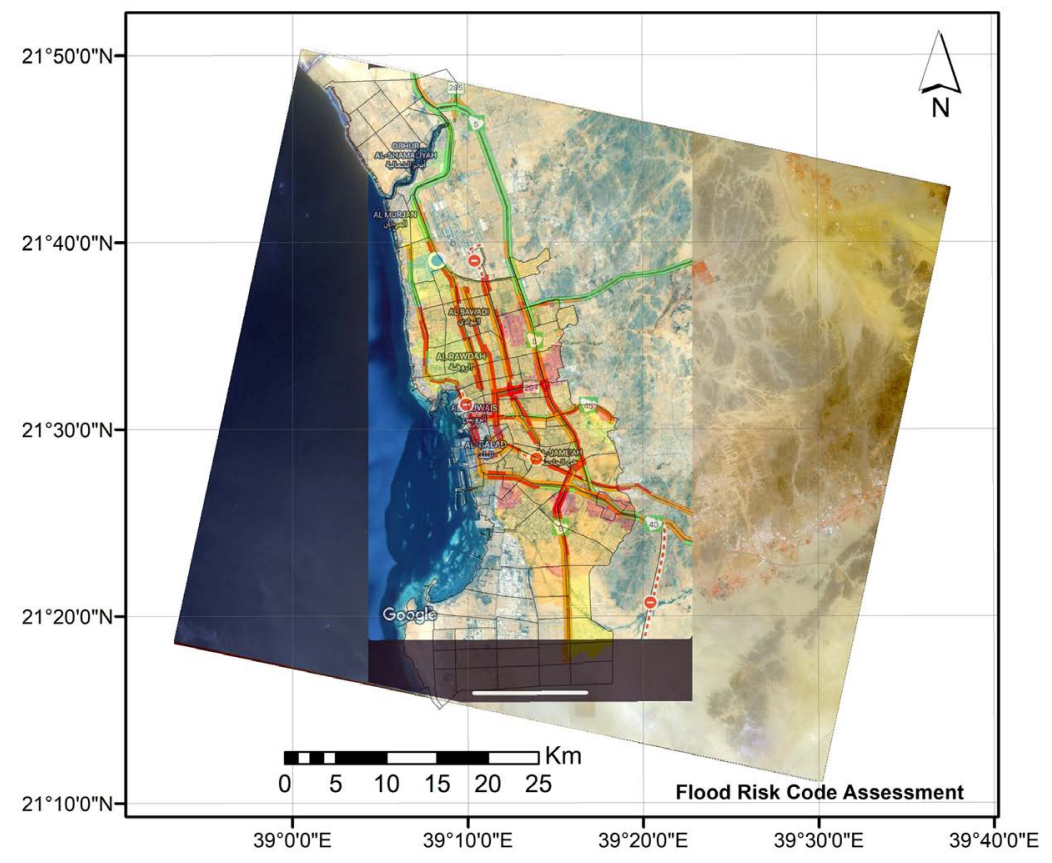

Figure 8. Flood Risk Code verification. 


\section{Conclusion}

This research article presented an efficient approach to accurately mapping the flood hazard areas in Jeddah city. The approach utilizes the use of remote sensing and GIS along with rainfall data to calculate the flood and basin morphometric parameters. The approach proposed uses two simple morphometric parameters (runoff depth and time of concentration) to generate a new Flood Risk Code for mapping hazard zones. By overlaying the flood risk code map with the districts layer, the hazard zones are delineated. The total runoff volume is 136.5 million $\mathrm{m}^{3}$ for a rainfall depth of $106.3 \mathrm{~mm}$. The results show that around $1 \mathrm{mil}-$ lion of Jeddah population live in 24 districts and an area of about $200 \mathrm{~km}^{2}$ are at extreme risk, more than 2 million of populations in 63 districts of area greater than $480 \mathrm{~km}^{2}$ are prone to major flood risk, the minority of Jeddah population are vulnerable to moderate to minor risk. The approach was verified using an actual map of flood hazard area due to 2017 rainfall storm and show its validity through the coincide of actual flood hazard classes with the obtained Flood Risk Code. The advantage of the approach is its ability to produce results using only topographical data and a satellite image, so it can be used in ungauged catchments, which is the case for most of the flood hazard regions in Saudi Arabia.

\section{Conflicts of Interest}

The authors declare no conflicts of interest regarding the publication of this paper.

\section{References}

[1] Foody, G.M., Ghoneim, E.M. and Arnell, N.W. (2004) Predicting Locations Sensitive to Flash Flooding in an Arid Environment. Journal of Hydrology, 292, 48-58. https://doi.org/10.1016/j.jhydrol.2003.12.045

[2] Mahmoud, S.H., Mohammad, F.S. and Alazba, A.A. (2013) A GIS-Based Approach for Determination of Potential Runoff Coefficient for Al-Baha Region, Saudi Arabia. International Conference on Sustainable Environment and Agriculture, IPCBEE, 57.

[3] Dawod, G.M., Mirza, M.N. and Al-Ghamdi, K.A. (2012) GIS-Based Estimation of Flood Hazard Impacts on Road Network in Makkah City, Saudi Arabia. Environmental Earth Sciences, 67, 2205-2215. https://doi.org/10.1007/s12665-012-1660-9

[4] Sherwood, J.M. (1993) Estimation of Flood Volumes and Simulation of Flood Hydrographs for Ungagged Small Rural Streams in Ohio. Ohio Department of Transportation, Columbus, Ohio.

[5] Farhan, Y. and Ayed, A. (2017) Assessment of Flash-Flood Hazard in Arid Watersheds of Jordan. Journal of Geographic Information System, 9, 717-751.

https://doi.org/10.4236/jgis.2017.96045

[6] Xiao, B., Wang, Q.H., Fan, J., Han, F.P. and Dai, Q.H. (2011) Application of the SCS-CN Model to Runoff Estimation in a Small Watershed with High Spatial Heterogeneity. Pedosphere, 21, 738-749. https://doi.org/10.1016/S1002-0160(11)60177-X

[7] Jasrotia, A. and Singh, R. (2006) Modeling Runoff and Soil Erosion in a Catchment Area, Using the GIS, in the Himalayan Region, India. Environmental Geology, 51, 
9-37. https://doi.org/10.1007/s00254-006-0301-6

[8] Saleh, A. and Al-Hatrushi, S. (2009) Torrential Flood Hazards Assessment, Management, and Mitigation, in Wadi Aday, Muscat Area, Sultanate of Oman, a GIS and RS Approach. The Egyptian Journal of Remote Sensing and Space Sciences, 12, $1-86$.

[9] Chang, H., Franczyk, J. and Kim, C. (2009) What Is Responsible for Increasing Flood Risks? The Case of Gangwon Province, Korea. Natural Hazards, 48, 339-354.

[10] Pandey, A. and Sahu, A.K. (2009) Generation of Curve Number Using Remote Sensing and Geographic Information System. Geospatial World.

https://www.geospatialworld.net/article/generationofcurvenumberusingremotesensi ngandgeographicinformationsystem/

[11] Dongquan, Z., Jining, C., Haozheng, W., Qingyuan, T., Shangbing, C. and Zheng, S. (2009) GIS-Based Urban Rainfall-Runoff Modeling Using an Automatic Catchment-Discretization Approach: A Case Study in Macau. Environmental Earth Sciences, 59, 65-472. https://doi.org/10.1007/s12665-009-0045-1

[12] Chen, J., Hill, A. and Urbano, L. (2010) A GIS-Based Model for Urban Flood Inundation. Journal of Hydrology, 373, 84-192.

[13] Sumarauw, J.S.F. and Ohgushi, K. (2012) Analysis on Curve Number, Land Use and Land Cover Changes and the Impact to the Peak Flow in the Jobaru River Basin, Japan. International Journal of Civil \& Environmental Engineering IJCEE-IJENS, 12, 17-23.

[14] Nasiri, A. and Alipur, H. (2014) Determination the Curve Number Catchment by Using GIS and Remote Sensing. International Journal of Environmental, Chemical, Ecological, Geological and Geophysical Engineering, 8, 342-345.

[15] Bansode, A. and Patil, K.A. (2014) Estimation of Runoff by Using SCS Curve Number Method and ArcGIS. International Journal of Scientific \& Engineering Research, 5, 1283-1287.

[16] Viji, R., Prasanna, P.R. and Ilangovan, R. (2015) GIS Based SCS-CN Method for Estimating Runoff in Kundahpalam Watershed, Nilgries District, Tamilnadu. Earth Sciences Research Journal, 19, 59-64.

[17] Gajbhiye, S. (2015) Estimation of Surface Runoff Using Remote Sensing and Geographical Information System. International Journal of $u$ - and e- Service, Science and Technology, 8, 113-122.

[18] Saghafian, B., Farazjoo, H., Bozorgy, B. and Yazdandoost, F. (2008) Flood Intensification Due to Changes in Land Use. Water Resources Management, 22, 1051-1067. https://doi.org/10.1007/s11269-007-9210-z

[19] Boglis, A., Evelpidou, N., Vassilopoulos, A., Lekkas, D.F., Gournellos, T. and Fountoulis, I. (2009) Urban Flood Modeling in Karlovassi Area-Samos Island, Greece. Proceedings of the 11 th International Conference on Environmental Science and Technology, Vol. 1, Chania, 3-5 September 2009, 83-91.

[20] Lingadevaru, D.C., Geovindaraju and Jayakumar, P.D. (2015) Flood Hazard Zonation Based on Basin Morphometry Using Remote Sensing and GIS Techniques: A Case Study of Tungabhadra and Hagari River Subcatchments North East Karnataka India. Journal of Geomatics, 9, 122-128.

[21] Omran, A., Schröder, D., El Rayes, A. and Geriesh, M. (2011) Flood Hazard Assessment in Wadi Dahab, Egypt Based on Basin Morphometry Using GIS Techniques. Herbert Wichmann Verlag, vde Verlag Gmbh, Berlin/Offenbach.

[22] Christofidis, A. (2008) Development of a GIS-Based Rainfall-Runoff Model. PhD 
Thesis, Department of Water Resources and Environmental Engineering, Faculty of Civil Engineering, National Technical University of Athens, Athens.

[23] Kilgore, J.L. (1997) Development and Evaluation of a GIS-Based Spatially Distributed Unit Hydrograph Model. Dissertation, Faculty of Virginia Polytechnic Institute and State University, Blacksburg.

[24] Pattison, I., Lane, S.N., Hardy, R.J. and Reaney, S. (2008) Sub-Catchment Peak Flow Magnitude and Timing Effects on Downstream Flood Risk. 10th National Hydrology Symposium, Exeter, 15-17 September 2008.

[25] Diakakis, M. (2011) A Method for Flood Hazard Mapping Based on Basin Morphometry: Application in Two Catchments in Greece. Natural Hazards, 56, 803-814. https://doi.org/10.1007/s11069-010-9592-8

[26] Subyani, A.M. and Hajjar, A.F. (2016) Rainfall Analysis in the Contest of Climate Change for Jeddah Area, Western Saudi Arabia. Arabian Journal of Geosciences, 9, 122. https://doi.org/10.1007/s12517-015-2102-2

[27] Sharif, H.O., Al-Juaidi, F.H., Al-Othman, A., Al-Dousary, I., Fadda, E., Jamal-Uddeen, S. and Elhassan, A. (2016) Flood Hazards in an Urbanizing Watershed in Riyadh, Saudi Arabia. Geomatics, Natural Hazards and Risk, 7, 702-720. https://doi.org/10.1080/19475705.2014.945101

[28] 210-VI-TR-55 (1986) Urban Hydrology for Small Watersheds. 2nd Edition, USDA, NRCS, CED.

https://www.nrcs.usda.gov/Internet/FSE_DOCUMENTS/stelprdb1044171.pdf

[29] Onen, F. and Bagatur, T. (2017) Prediction of Flood Frequency Factor for Gumbel Distribution Using Regression and GEP Model. Arabian Journal for Science and Engineering, 42, 3895-3906. https://doi.org/10.1007/s13369-017-2507-1

[30] Prodanovic, P. and Simonovic, S. (2007) Development of Rainfall Intensity Duration Frequency Curves for the City of London under the Changing Climate. Report 58, Department of Civil and Environment Engineering, the University of Western Ontario, London.

[31] Khalil, R. (2017) Determination of Potential Runoff Coefficient Using GIS and Remote Sensing. Journal of Geographic Information System, 9, 752-762. https://doi.org/10.4236/jgis.2017.96046

[32] 210-VI-NEH (2010) National Engineering Handbook. USDA, NRCS, Part 630. https://directives.sc.egov.usda.gov/OpenNonWebContent.aspx?content=27002.wba 